早期公開

一技術報告一

TaqMan 法に基づくヒト DNA 定量キットの比較

深川貴志，綿引晴彦，三田裕介，北山哲史，藤井宏治，水野なつ子

\author{
科学警察研究所 \\ ₹277-0882 千葉県柏市柏の葉 6-3-1
}

\title{
Comparison of human DNA quantification kits based on a TaqMan assay
}

Takashi Fukagawa, Haruhiko Watahiki, Yusuke Mita, Tetsushi Kitayama, Koji Fujii and Natsuko Mizuno

National Research Institute of Police Science

6-3-1, Kashiwanoha, Kashiwa, Chiba 277-0882, Japan

(Received 21 June 2021; accepted 7 September 2021;

Published online 14 October 2021 in J-STAGE DOI: 10.3408/jafst.821)

Human DNA quantification is an important step for subsequent short tandem repeat (STR) analysis and interpretation because it can provide various information on the quantity and quality for the extracted DNA. In this study, we compared four commercially available quantification kits based on a TaqMan assay and an intercalating-dye based quantification kit. The following three points were investigated: 1) variations of the average peak heights among individuals when $1 \mathrm{ng}$ of DNA, the amount being determined by each quantification kit, was amplified using GlobalFiler and Yfiler Plus PCR Amplification Kits, 2) effect of the presence of a female DNA on the quantification of male DNA, and 3) relationship between "Degradation Index" and the STR electropherograms. The average peak heights generated using GlobalFiler showed less individual-dependent variations in the four TaqMan based kits than the intercalating-dye based kit. The average peak heights generated using Yfiler Plus showed similar variations among the three TaqMan based kits capable of male DNA quantification along with total human DNA. The presence of a large amount of female DNA had little effect on male DNA quantification in all the three kits. When highly degraded DNA samples were quantified, the "Degradation Indices" differed significantly among three kits. It was probably due to the different amplicon sizes of the long fragment targets among kits. Before implementing a new human DNA quantification kit in casework, it is essential to understand the characteristics of the adopted quantification kit.

Key words: Forensic science, Human DNA quantification kit, Degradation index 


\section{緒 言}

現在, DNA 型鑑定による個人識別では, Short Tandem Repeat（STR）領域を検査するSTR 型検 査が主流となっている。

STR 型検査においては，まず試料から抽出精製 したDNA 溶液についてヒトDNA 定量を行い, DNAの量打よび品質を確認し，適切な鋳型 DNA 量から STR 領域を PCR 増幅する。次に，多色の 蛍光色素により標識された増幅産物をキャピラリー 電気泳動装置により分離および検出し，解析ソフト ウェアでピークを検出し型判定を行う1)。ヒト DNA 定量では，用いる試薬によっては，ヒト DNAの量だけでなく，阻害物質の存在，ヒト DNA の変性の程度，男性 DNAの存在およびその 量などの情報も得ることもできる ${ }^{2-4)}$ 。これらの情 報は，PCR 反応液の調整に用いるほか， STR 型検 查で最終的に得られるエレクトロフェログラムの解 釈にも非常に有用であることから，ヒトDNA 定量 はSTR 型検査において重要な工程の一つといえ る.

法科学分野におけるヒト DNA 定量には，リアル タイム PCR 装置を用いた定量 PCR 法が用いられ ることが多い。現在, 定量 PCR 法を用いたヒト DNA 定量キットは，日本の警察で広く用いられて いるタカラバイオ製のヒトゲノム DNA 定量キット Ver. $2^{5)}$ をはじめとした複数のキットが販売されて いる.これらのヒト DNA 定量キットの標的配列に は, 検出感度の向上のために, ヒトゲノム上に複数 コピーが存在する配列（以下「マルチコピー配列」） が主に用いられている2-4,6).

定量 PCR 法の 1 つである TaqMan 法に基づくヒ ト DNA 定量キットには，アプライドバイオシステ ムズ製の Quantifiler Trio DNA Quantification Kit お よび Quantifiler HP DNA Quantification Kit, プロ メガ製の PowerQuant System ならびにキアゲン製 の Investigator Quantiplex Proなどがある。これら の定量キットは，いずれも複数の常染色体上に存在 する短めのマルチコピー配列, 長めのマルチコピー 配列㧍よびY 染色体上のマルチコピー配列（ただ し Quantifiler HP は除く）を同時に定量可能であ
る2-4)。また，これらの定量キットは，いずれも開 発時の検証（Developmental validation）が行われ ており 2,7-9)，キットの性能などの様々な項目につい て検証されている。しかしながら，検証はキットご とに異なる検証用試料が用いられているため，各 キットの検証結果を単純に比較することはできな い。またキット間で増幅する標的配列は異なるた め, 同一試料に対して各キットがどのような定量結 果を示すかについては不明である。さらに各キット で増幅されるマルチコピー配列は，個人間で保有す るコピー数が異なるコピー数多型が存在する10,11) た め，キットと試料の組み合わせによっては適切な定 量值が得られない可能性がある。そこで本研究で は，各種定量キットから得られた定量值により鋳型 DNA 量を調整した場合におけるSTR 型検査の個 人間のピーク高のばらつき，女性 DNAの存在が男 性 DNAの定量值に及ぼす影響および Degradation Index（試料 DNA の変性の程度を表す指標，以下 「DI 值」）とエレクトロフェログラムの関係性の 3 項目について, 同一試料を複数のヒトDNA 定量 キットで測定することで比較した.

\section{材料および方法 \\ 1 ヒト DNA 試料}

本研究の実施抢よびヒト試料の収集は，科学警察 研究所ヒトゲノム・遺伝子解析研究倫理審査委員会 の承認を得て実施した（承認番号 : 32-1 (74)).

成人日本人男性 8 名, 成人日本人女性 7 名加採 取した血液，ならびに作製から 1 年， 5 年， 10 年， 15 年，18年， 21 年， 24 年抢よび 25 年経過した 1 名分 の陳旧血痕から，EZ1 DNA Investigator kit（キア ゲン）を用いてDNAを抽出した。をた，成人日本 人女性 1 名から採取した血液から，QIAamp DNA Investigator kit（キアゲン）を用いて DNA を抽出 し, Concentrator 5301 （エッペンドルフ）により DNA 溶液を真空濃縮した。

\section{2 ヒト DNA 定量}

DNA 溶液は, QuantStudio 5 Real-Time PCR System（アプライドバイオシステムズ）または7500 Real-Time PCR System (アプライドバイオシステ ムズ）を用いて，最大 5 種類のヒト DNA 定量キッ 
ト (Qunatifiler Trio DNA Quantification Kit（以下 「Trio」, アプライドバイオシステムズ), Qunatifiler HP DNA Quantification Kit（以下「HP」, アプ ライドバイオシステムズ), PowerQuant System (以下「PQ」, プロメガ), Investigator Quantiplex Pro Kit（以下「QPP」，キアゲン）およびヒトゲノ ムDNA定量キットVer.2（以下「TK2」，タカラバ イオ）によるヒトDNA定量を行った。TK2 は TaqMan 法ではなくインターカレーター色素に基づ いたヒト DNA 定量キットであるが，現在警察で広 く用いられているキットであることから，TaqMan 法に基づくキットとの比較のために用いた，反応 は，Trio， HP，PQ 抢よび QPPについては QuantStudio 5 用のマニュアル2,3,12)に，TK2 につい ては7500 Real-Time PCR System 用のマニュアル5) に従って行った。なお，データコレクションおよび 解析ソフトは, Trio 拈よびHPについてはHID Real-Time PCR Analysis Software v1.3を，PQ 掞よ びQPPについては Design and Analysis Software v1.5.1を，TK2については HID Real-Time PCR Analysis Software v1.2 を用いた。抽出 DNA 溶液は それぞれ $2 \mu \mathrm{L}$ を用い，反応は 3 回ずつ実施した。 定量值は, 3 回の結果の平均とした.

なお， TK2 以外のキットでは複数の標的配列が 存在するが，その標的配列はキットにより名称が異 なるため, その標的配列の名称について，常染色体
上の短い方の標的配列を「Short」, 常染色体上の長 い方の標的配列を「Long」，打よびY染色体上の 標的配列を「Y」とした（Table 1). TK2に抢いて は，標的配列が 1 種類であり，その塩基長が他キッ トの Long と類似していることから, 標的配列の名 称を「Long」とした（Table 1).

\section{STR 型検査}

GlobalFiler PCR Amplification Kit（以下 $\lceil\mathrm{GF}\rfloor$, アプライドバイオシステムズ）および Yfiler Plus PCR Amplification Kit (以下「YFP」, アプライド バイオシステムズ）を用いて， STR 型検査を行っ た。検査は，それぞれのユーザーガイド13,14)に従っ て行った。PCR 増幅に用いた鋳型 DNA 量は, GF では「Short」の定量値（TK2 のみ「Long」の定量 值）を，YFPでは「Y」の定量值を基に $1 \mathrm{ng}$ とし た. PCR サイクル数は GF では29サイクル，YFP では30サイクルとした。PCR 装置は GeneAmp PCR System 9700 (アプライドバイオシステムズ) を用い，電気泳動装置は 3500xL Genetic Analyzer （アプライドバイオシステムズ）を用いた.

データコレクションソフトには3500 Series Data Collection Software v3.1（アプライドバイオシステ ムズ）を用いた。電気泳動は，GFをたは YFPの ユーザーガイド13,14)に従って行った.

泳動データの解析は, GeneMapper ID - X Software v1.4（アプライドバイオシステムズ）を用

Table 1 Targets name and amplicon size of the each human DNA quantification kit.

\begin{tabular}{|c|c|c|c|c|}
\hline \multirow[b]{2}{*}{ Quantification kit } & \multicolumn{3}{|c|}{ Target length (bp) } & \multirow[b]{2}{*}{ Assay } \\
\hline & $\begin{array}{l}\text { Short autosomal } \\
\text { target (Short) }\end{array}$ & $\begin{array}{l}\text { Long autosomal } \\
\text { target (Long) }\end{array}$ & $\begin{array}{l}\text { Y chromosome } \\
\text { target }(\mathrm{Y})\end{array}$ & \\
\hline $\begin{array}{c}\text { Quantifiler Trio DNA } \\
\text { Quantification Kit }\end{array}$ & 80 & 214 & 75 & TaqMan \\
\hline $\begin{array}{l}\text { Quantifiler HP DNA } \\
\text { Quantification Kit }\end{array}$ & 80 & 214 & - & TaqMan \\
\hline PowerQuant System & 84 & 294 & $81 \& 136$ & TaqMan \\
\hline $\begin{array}{c}\text { Investigator } \\
\text { Quantiplex Pro }\end{array}$ & 91 & 353 & 81 & TaqMan \\
\hline $\begin{array}{c}\text { Human DNA } \\
\text { Quantification Kit Ver.2 }\end{array}$ & - & 207 & - & TB Green* \\
\hline
\end{tabular}

* TB Green is synthesized by Takara Bio and has the same chemical structure as that of SYBR Green I. 
いた．解析に必要なパネルなどのファイルは, アプ ライドバイオシステムズブランドを有するサーモ フィッシャーサイエンティフィック社が提供をして いる GlobalFiler v1.0.1 ( https: // downloads. thermofisher.com/GlobalFiler_Analysis/GlobalFiler _Analysis_Files_v1.0.1X.zip）を用いた。解析にお いては, スタターフィルターを有効にして解析し, スタター排除の閾值はサーモフィッシャーサイエン ティフィックが設定した Marker specific stutter ratioの值 ${ }^{13,14)}$ とした. ピークの検出閾值は, 著者ら が過去に STR 型検査キットの評価15,16)において採

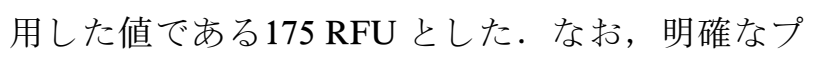
ルアップと判断できたピーク17) およびアーティファ クトと判断できたピーク ${ }^{14,18)}$ は除外した.

\section{4 定量キット間の比較}

以下の 3 項目について, 定量キット間で比較し た. 特に記載がない限り, 定量值の比較には Short の定量値を, 男性 DNAの定量值の比較にはY 定量值を用いた。

\section{1 各種定量キットから得られた定量值により鋳 型 DNA 量を調整した場合の STR 型検査のピー ク高の個人間のばらつき}

成人日本人男性 6 名抢よび成人日本人女性 6 名の 血液から抽出した DNA 溶液について, まず Trio を用いてヒトDNA 定量を行い，その結果に基づい て約 $1 \mathrm{ng} / \mu \mathrm{L}$ になるように希釈した。希釈 DNA 溶 液を 5 種類のキットで定量し, 各キットの定量結果 を基にして STR 型検査を行った. なお，STR 型検 査には GFを用いた。 また， Trio，PQ 抢よび QPP については，男性試料に対してYFP も実施した。 各試料について， 3.5 反応分の反応液を $1 つ の$ チューブに調製したのち, チューブ 3 本に 1 反応分 ずつ分注して, 同時に PCR を行った.

STR 型検査のピーク高のばらつきの評価には, エレクトロフェログラムのアレルピーク高を用い た. まず，各エレクトロフェログラムの各検査座位 のピーク高を, 以下の(1)から(6)のと抢りにしてア レル 1 個分のピーク高に換算した.

(1) GFにおいて検査座位のSTR 型がへテロ接 合体の場合 : 2 本のピーク高を平均した.

(2) GFにおいて検査座位のSTR 型がホモ接合
体の場合：ピーク高を $1 / 2$ にした。

(3) GF の Yindel 座位および DYS391座位： ピーク高をそのまま用いた。

(4) YFPに抢いてDYS385座位および DYF387S1 座位を除く検査座位 : ピーク高を そのまま用いた。

(5) YFPのDYS385座位：6試料すべてで DYS385 座位のピークは 2 本であったことか ら，2 本のピーク高を平均した。

（6） YFP の DYF387S1 座位：コピー数多型が報 告されている19)ため，まず相対的 PCR 増幅 効率（RA）を既報19) から一部改変し, 次の 式で算出した.

$$
R A=\frac{1}{3}\left(\frac{23 h_{1}}{H_{1}}+\frac{23 h_{2}}{H 2}+\frac{23 h_{3}}{H_{3}}\right)
$$

$h_{\mathrm{i}}$ は $\mathrm{i}$ 番目の反応における DYF387S1 座位の アレルピーク，マイナススタターおよびプラ ススタターのピーク高の合計值であり， $\mathrm{H}_{\mathrm{i}}$ は $\mathrm{i}$ 番目の反応に打けるDYS385, DYF387S1 を除く座位のアレルピーク, マイ ナススタターおよびプラススタターのピーク 高の合計值である．各スタターのピーク高 は，スタターフィルターを無効にして泳動 データを再解析し, 取得した。 6 試料のう ち, RAが 1 程度になった 2 試料（RA： 1.041および1.088）ではピークが 1 本であっ たので, ピーク 1 本につきアレル 1 個分と判 断し，ピーク高をそのまま用いた。また， RA が 2 程度になった 4 試料（RA：2.097, 2.110，2.211および2.346）ではピークが 2 本であったので, ピーク 1 本につきアレル 1 個分と判断し， 2 本のピーク高を平均した.

次に, 各エレクトロフェログラムについて全検査 座位のアレル 1 個分のピーク高から平均を算出し, その值を「そのエレクトロフェログラムの換算ピー ク高」とした．同一個人の 3 反応分の「そのエレク トロフェログラムの換算ピーク高」の平均を算出 し，その值を「その個人のアレル 1 個分のピーク高」 とした．GFでは 12 試料分の「その個人のアレル 1 個分のピーク高」から, YFP では 6 試料分の「そ の個人のアレル 1 個分のピーク高」から変動係数 
（標準偏差/平均値）を算出した.

\section{2 女性 DNA の存在が男性 DNA（Y）の定量値 に及ぼす影響}

成人日本人男性 3 名, 成人日本人女性 2 名の血液 から抽出した DNA 溶液および成人日本人女性 1 名 の血液から抽出し濃縮したDNA 溶液を用いて実施 した。各抽出 DNA 溶液について，まず Trioでヒ 卜DNA 定量を行ったのち，その定量值に基づいて 「男性 DNA 濃度が一定の男女混合 DNA 溶液」お よび「合計 DNA 濃度が一定の男女混合 DNA 溶液」 を調整した。「男性 DNA 濃度が一定の男女混合 DNA 溶液」では，男性 DNA 濃度の終濃度を0.02 $\mathrm{ng} / \mu \mathrm{L}$ とし, 男性 DNA 濃度：女性 DNA 濃度が $1: 0,1: 1,1: 5,1: 25,1: 125,1: 625,1:$ 3125 となるように調整した。「合計 DNA 濃度が一 定の男女混合DNA 溶液」では, 混合後の合計 DNA 濃度の終濃度が $0.5 \mathrm{ng} / \mu \mathrm{L}$ とし, 男性 DNA 濃度：女性 DNA 濃度が 1 : $0,80 ： 1 ， 40: 1$, $20: 1,10: 1,4: 1,2: 1,1: 1,1: 2,1: 4$, $1: 10,1: 20,1: 40,1: 80,0: 1$ となるように 調整した。なお，「合計 DNA 濃度が一定の男女混 合 DNA 溶液」は，男女ともに異なる個人試料の 2 種類の組み合わせのものを調整した.

調整した各混合 DNA 溶液について, Trio, PQ およびQPPにより DNAを定量した.

\subsection{DI 値とエレクトロフェログラムの関係性}

1 年, 5 年, 10 年, 15 年, 18 年, 21 年, 24 年打よ び 25 年経過した 1 名分の陳旧血痕から抽出した DNA 溶液を用いた。各抽出 DNA 溶液について, Trio，HP，PQ 抢よび QPPによりDNAを定量 し，DI 值を算出した．DI 值の算出は，Trio および HP ではデータコレクションおよび解析ソフトの標 準機能により，PQではPowerQuant Analysis Software v1.0により，QPPでは QIAGEN Quantification Assay Data Handling and STR Setup Tool v3.4.3により算出した。Trioの定量結果を基にし て GFを実施した。

\section{結果および考察}

1 各種定量キットから得られた定量値により鋳型 DNA 量を調整した場合の STR 型検査のピーク 高の個人間のばらつき

各定量キットから得られた定量值により鋳型 DNA 量を揃えたときのSTR 型検査のピーク高に おける個人間のばらつきを検証するために，各試料 の「その個人のアレル 1 個分のピーク高」から平均 值, 標準偏差および変動係数を算出した（Table 2).

GF に拈け Trio，HP，PQ および QPP の個人 間の変動係数はそれぞれ0.0964，0.1040，0.1293お よび 0.1136 と0.1付近の值であったのに対し，TK2

Table 2 Coefficient of variation (CV) calculated from "adjusted one-allele peak height in electropherogram" of 12 individuals (GlobalFiler) or 6 individuals (Yfiler Plus).

\begin{tabular}{|c|c|c|c|c|c|c|}
\hline \multirow[b]{2}{*}{ Quantification kit } & \multicolumn{3}{|c|}{ GlobalFiler $(\mathrm{n}=12)$} & \multicolumn{3}{|c|}{ Yfiler Plus $(n=6)$} \\
\hline & $\begin{array}{l}\text { Mean } \\
\text { (RFU) }\end{array}$ & $\begin{array}{c}\mathrm{SD} \\
(\mathrm{RFU})\end{array}$ & $\mathrm{CV}$ & $\begin{array}{l}\text { Mean } \\
\text { (RFU) }\end{array}$ & $\begin{array}{c}\text { SD } \\
(\mathrm{RFU})\end{array}$ & $\mathrm{CV}$ \\
\hline $\begin{array}{c}\text { Quantifiler Trio DNA } \\
\text { Quantification Kit }\end{array}$ & 5819 & 561.0 & 0.0964 & 5991 & 1092 & 0.1823 \\
\hline $\begin{array}{l}\text { Quantifiler HP DNA } \\
\text { Quantification Kit }\end{array}$ & 6796 & 706.6 & 0.1040 & — $^{*}$ & —* & — $^{*}$ \\
\hline PowerQuant System & 7263 & 939.3 & 0.1293 & 10370 & 1417 & 0.1366 \\
\hline $\begin{array}{l}\text { Investigator } \\
\text { Quantiplex Pro }\end{array}$ & 8682 & 986.7 & 0.1136 & 8469 & 1467 & 0.1732 \\
\hline $\begin{array}{c}\text { Human DNA } \\
\text { Quantification Kit Ver.2 }\end{array}$ & 4257 & 931.0 & 0.2187 & —* $^{*}$ & —* & - $^{*}$ \\
\hline
\end{tabular}

* STR analysis using Yfiler Plus was not performed because these kits do not quantify Y chromosome. 


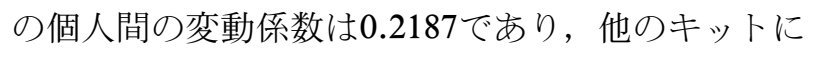
比べて約2倍高い值となった（Table 2). この結果 から，同一キットから得られた定量值を基に鋳型 DNA 量を調整して PCR をした場合, TK2では他 のキットに比べて, 試料の由来となる個人によって STR 型検查結果のピーク高がより変動する可能性 が示唆された. 変動係数が大きい原因の一つとし て, TK2 では他の 4 種類のキットよりも, 標的配 列のコピー数多型の個人差が大きい可能性が考えら れる.

また, YFPにおける個人間の変動係数は Trio が 0.1823, PQが0.1366, QPPが0.1732であり（Table 2), Trio および QPPは近い值となったが, PQ はそれらより小さい值であった。この結果から, 同 一キットから得られた Y の定量值を基に鋳型 DNA 量を調整して PCR をした場合, Y-STR 型検査結 果のピーク高の変動は, Trio と QPP では同程度で あり， PQ は Trio 抢よび QPP に比べて変動がより
少ない可能性がある.

\section{2 女性 DNA の存在が男性 DNA（Y）の定量値 に及ぼす影響}

最初に, 男性 DNA 濃度が一定の男女混合 DNA 溶液についてそれぞれのキットで定量をしたとこ ろ，いずれのキットについても，Yの定量值はほぼ 一定であり，Short の定量值は女性 DNA 濃度に応 じた值を示した（Fig. 1).

次に, 合計 DNA 濃度が一定の男女混合 DNA 溶 液について，それぞれのキットで定量をしたとこ ろ，いずれのキットについても， Shortの定量值は ほとんど一定であり，Y の定量值は男性 DNA 濃度 に応じた值を示した（Fig. 2)。しかしながら，2 種 類の混合の組み合わせのうち，「組み合わせ $1 」 の$ Trio（Fig. 2A）抢よび QPP (Fig. 2C)，「組久合わ せ2」の QPP（Fig. 2F）では, 男性 DNAの混合 比率が高い場合に, Short と Y の定量值の乘離がみ られた。なお，これらの例では男性 DNAのみを定
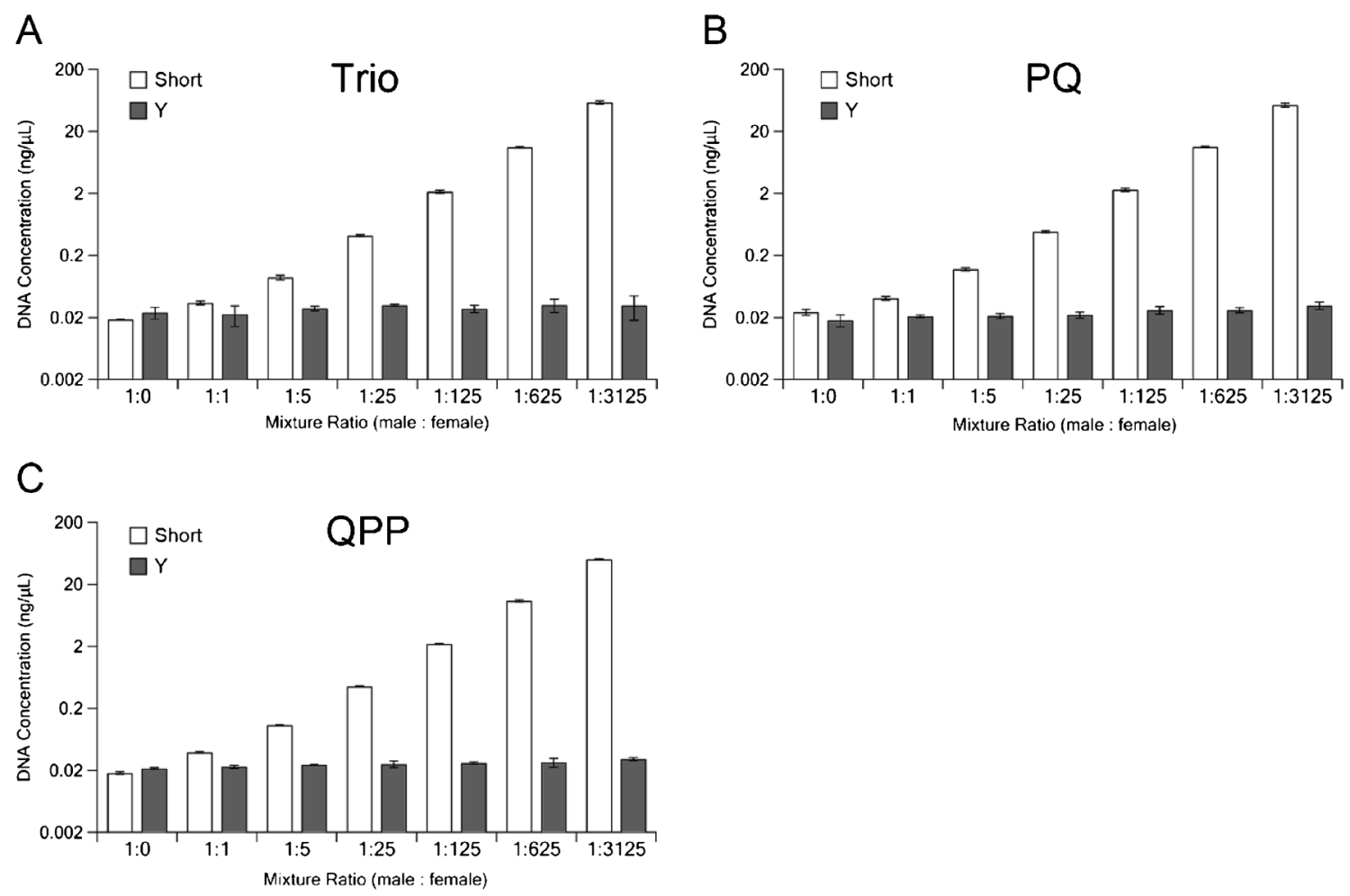

Fig. 1 The mean quantification results for the mixture of the male DNA with the high concentrated female DNA in triplicate using Quantifiler Trio DNA Quantification Kit (Trio), PowerQuant System (PQ) and Investigator Quantiplex Pro (QPP). 
A

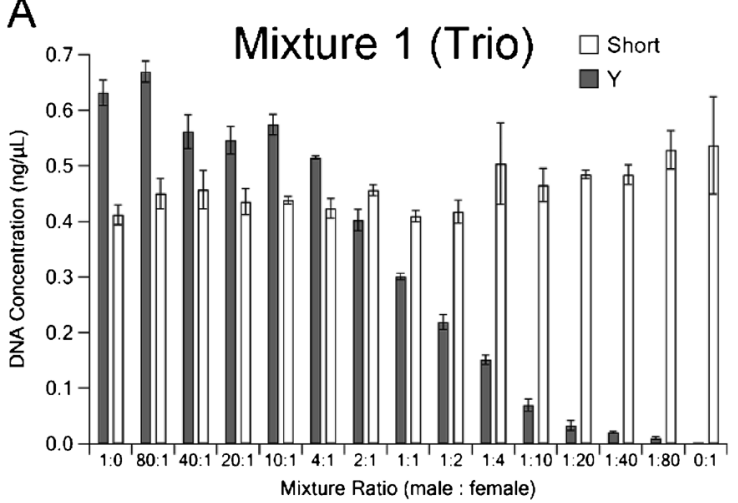

B

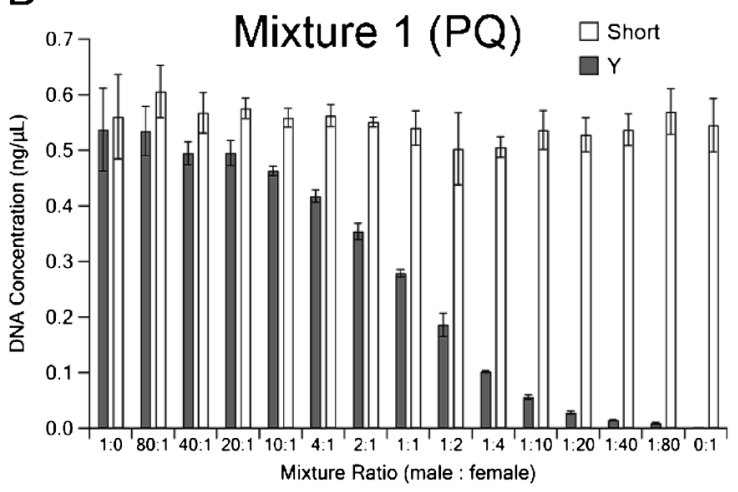

C

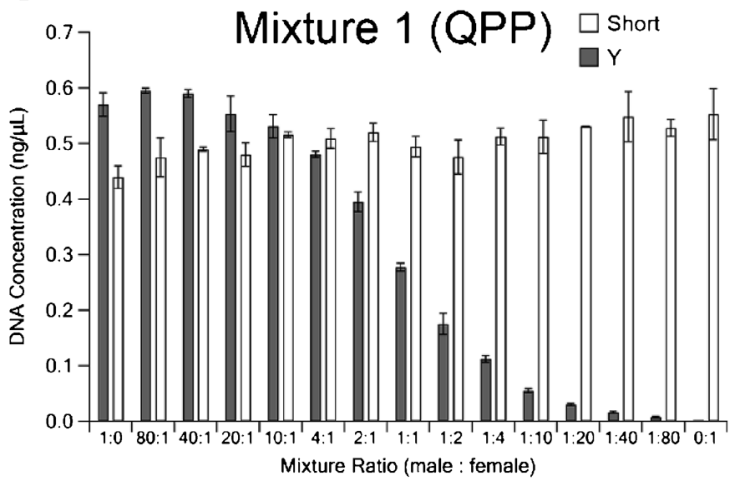

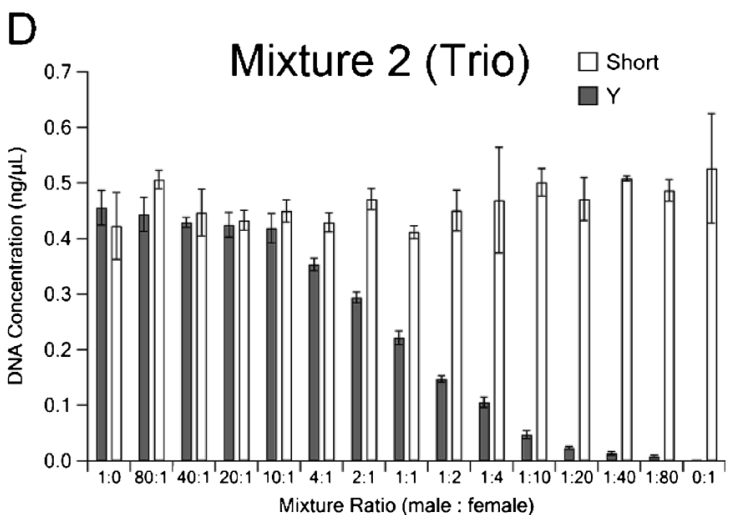

$E$

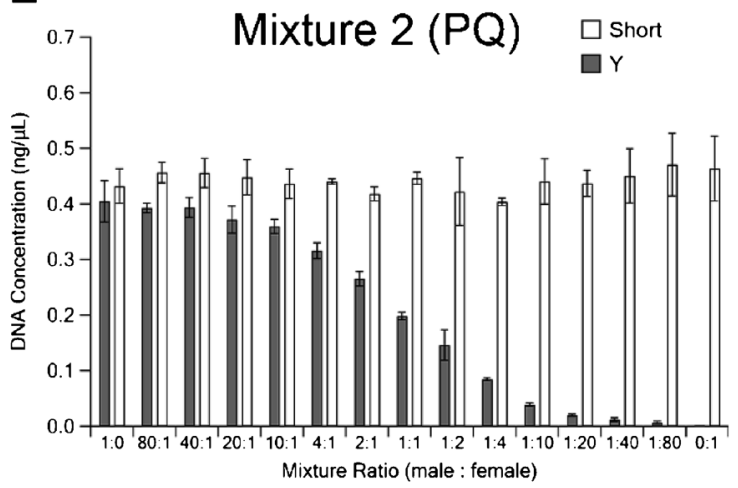

F

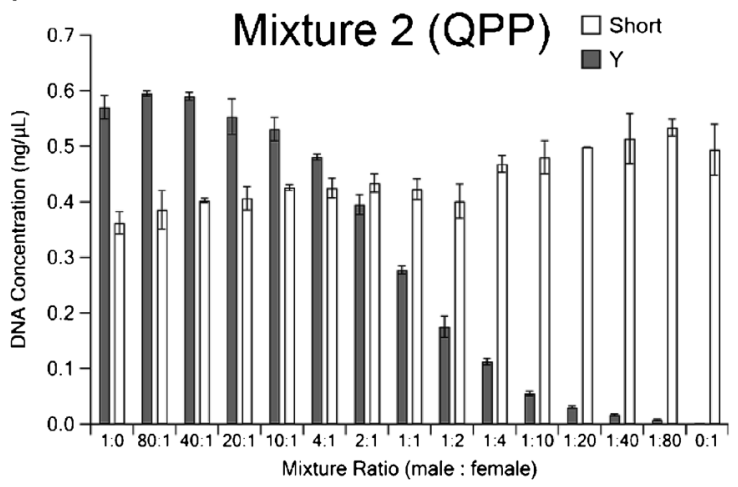

Fig. 2 The mean quantification results for the two male/female mixture samples (Mixture 1: Panel A-C, Mixture 2: Panel D-F) with constant total DNA concentration in triplicate Quantifiler Trio DNA Quantification Kit (Trio), PowerQuant System (PQ) and Investigator Quantiplex Pro (QPP). Both male/female donors were different between the two mixtures.

量した場合 (男性 DNA 濃度 : 女性 DNA 濃度が 1 : 0）に抢いても同様の傾向となったことから，乘離 の原因は男性 DNA と定量キットの組み合わせにあ ると考えられる。一方，PQ では男性 DNAのみを 定量した場合に抢いても，Short とYの定量值の乘 離はみられなかった（Fig. 2B，E）。Trio抢よび $\mathrm{QPP}$ と異なり，PQ では $\mathrm{Y}$ の標的配列が 2 種類と
なっている (Table 1)。これは, 標的配列のコピー 数のばらつきが Short とYの定量值の比に与える 影響を最小限に抑えるためと PQのマニュアル゙に 説明されており，今回 PQにおいて Short と $\mathrm{Y} の$ 定量值に乘離が生じなかった要因である可能性があ る。また，Trio 抢よび QPPでみらた Short と Y の定量值の乘離は, Short の定量値よりも Y の定量 
值の方が高くなる場合のみであった（Fig. 2A，C， F)。しかし，男性 DNA と定量キットの組み合わせ によっては, Shortの定量值よりも Y の定量值の方 が低くなり，男性 DNAのみの定量にも関わらず女 性 DNA が混合しているような定量結果となること も考えられることから, 定量の結果のみから男女混 合の推定には限界があることに留意する必要があ る.

\section{DI 值とェレクトロフェログラムの関係性}

DI 值（Degradation Index）は，試料 DNA の変 性の程度を示す指標であり，Shortの定量值を Long の定量值で除算することで算出される．経過 年数の異なる陳旧血痕から抽出した各 DNA 溶液に ついて，それぞれのキットにより定量したときの Short の定量值，Long の定量值および DI 值を Table 3 に示す。また，各 DNA 溶液を STR 型検査し て得られたエレクトロフェログラムをアレル検出率 が高い順に並べ，対応する各キットのDI 值を Fig. 3 に示す.

これらの結果から，同じ DNA 溶液でもキットに よって DI 值に差がある場合があり，特にアレル検 出率が $85.4 \% \sim 41.5 \%$ DNA 溶液では，キット間 の DI 值の差が大きくなっていた４種類のキット のうち，Trio と HPでは，すべての試料から DI 值 が算出され，アレル検出率が53.7\% (21年経過血痕) および41.5\%（18年経過血痕）の 2 試料を除いて， DI 值は近い值となった。アレル検出率が高い順に 並べた場合，Tio と HPによるDI 值はアレル検出 率80.5\%（15年経過血痕）までは最大5.74 と低い值 で推移していたが，アレル検出率 $53.7 \%$ から DI 值 は最低でも31.4と高い值を示した（Fig. 3）。一方， $\mathrm{PQ}$ 抢よび QPP では，アレル検出率が $100 \%$ の 4 試 料では DI 值が最大でも7.14 と低い值であったもの の，アレル検出率が $85.4 \%$ （25年経過血痕）および 80.5\%（15年経過血痕）の試料では PQ の DI 值は それぞれ32.75抢よび32.14，QPP の DI 值はそれぞ れ106.38および155.81と高い值を示しており，Trio および $\mathrm{HP} ， \mathrm{PQ}$ ならびに QPP のあいだで DI 值に 大きな差が生じていた（Fig. 3)。また，PQではア レル検出率が $41.5 \%$ の試料において，QPP ではア レル検出率が $53.7 \%$ および $41.5 \%$ の試料において,
Table 3 The mean quantification results $(n=3)$ for various old bloodstain samples among Quantifiler Trio DNA Quantification Kit (Trio), Quantifiler HP DNA Quantification Kit (HP), PowerQuant System (PQ) and Investigator Quantiplex Pro (QPP).

\begin{tabular}{|c|c|c|c|c|}
\hline Age & Kit & $\begin{array}{c}\text { Short } \\
(\mathrm{ng} / \mu \mathrm{L})\end{array}$ & $\begin{array}{c}\text { Long } \\
(\mathrm{ng} / \mu \mathrm{L})\end{array}$ & $\begin{array}{l}\text { Degradation } \\
\text { Index }\end{array}$ \\
\hline \multirow{4}{*}{1 year } & Trio & 2.1961 & 2.1841 & 1.01 \\
\hline & HP & 2.2432 & 2.1607 & 1.04 \\
\hline & PQ & 2.1821 & 2.4555 & 0.89 \\
\hline & QPP & 2.2819 & 2.4092 & 0.95 \\
\hline \multirow{4}{*}{5 years } & Trio & 2.5117 & 3.4521 & 0.73 \\
\hline & HP & 2.7171 & 3.5284 & 0.77 \\
\hline & PQ & 2.5977 & 2.2668 & 1.15 \\
\hline & QPP & 2.8647 & 1.7131 & 1.67 \\
\hline \multirow{4}{*}{10 years } & Trio & 1.4140 & 0.8838 & 1.60 \\
\hline & $\mathrm{HP}$ & 1.4319 & 0.8705 & 1.65 \\
\hline & PQ & 1.4408 & 0.3628 & 3.97 \\
\hline & QPP & 1.4986 & 0.2102 & 7.14 \\
\hline \multirow{4}{*}{15 years } & Trio & 0.5716 & 0.1038 & 5.51 \\
\hline & $\mathrm{HP}$ & 0.5533 & 0.0967 & 5.74 \\
\hline & PQ & 0.6566 & 0.0204 & 32.14 \\
\hline & QPP & 0.6263 & 0.0041 & 155.81 \\
\hline \multirow{4}{*}{18 years } & Trio & 0.1040 & 0.0003 & 533.07 \\
\hline & $\mathrm{HP}$ & 0.0911 & 0.0016 & 56.57 \\
\hline & PQ & 0.1060 & N.D. & - \\
\hline & QPP & 0.0908 & N.D. & - \\
\hline \multirow{4}{*}{21 years } & Trio & 0.2115 & 0.0024 & 88.97 \\
\hline & $\mathrm{HP}$ & 0.1917 & 0.0062 & 31.34 \\
\hline & PQ & 0.2360 & 0.0004 & 544.69 \\
\hline & QPP & 0.1923 & N.D. & - \\
\hline \multirow{4}{*}{24 years } & Trio & 2.1137 & 1.7900 & 1.18 \\
\hline & $\mathrm{HP}$ & 2.2185 & 1.7401 & 1.28 \\
\hline & PQ & 2.2104 & 0.7687 & 2.88 \\
\hline & QPP & 2.3516 & 0.5851 & 4.02 \\
\hline \multirow{4}{*}{25 years } & Trio & 0.8233 & 0.1667 & 4.95 \\
\hline & $\mathrm{HP}$ & 0.8157 & 0.1613 & 5.08 \\
\hline & PQ & 0.9900 & 0.0302 & 32.75 \\
\hline & QPP & 0.9320 & 0.0088 & 106.38 \\
\hline
\end{tabular}

N.D. means not detected and "_-" means that degradation index could not be calculated since the DNA quantity of the long fragment was not determined. 


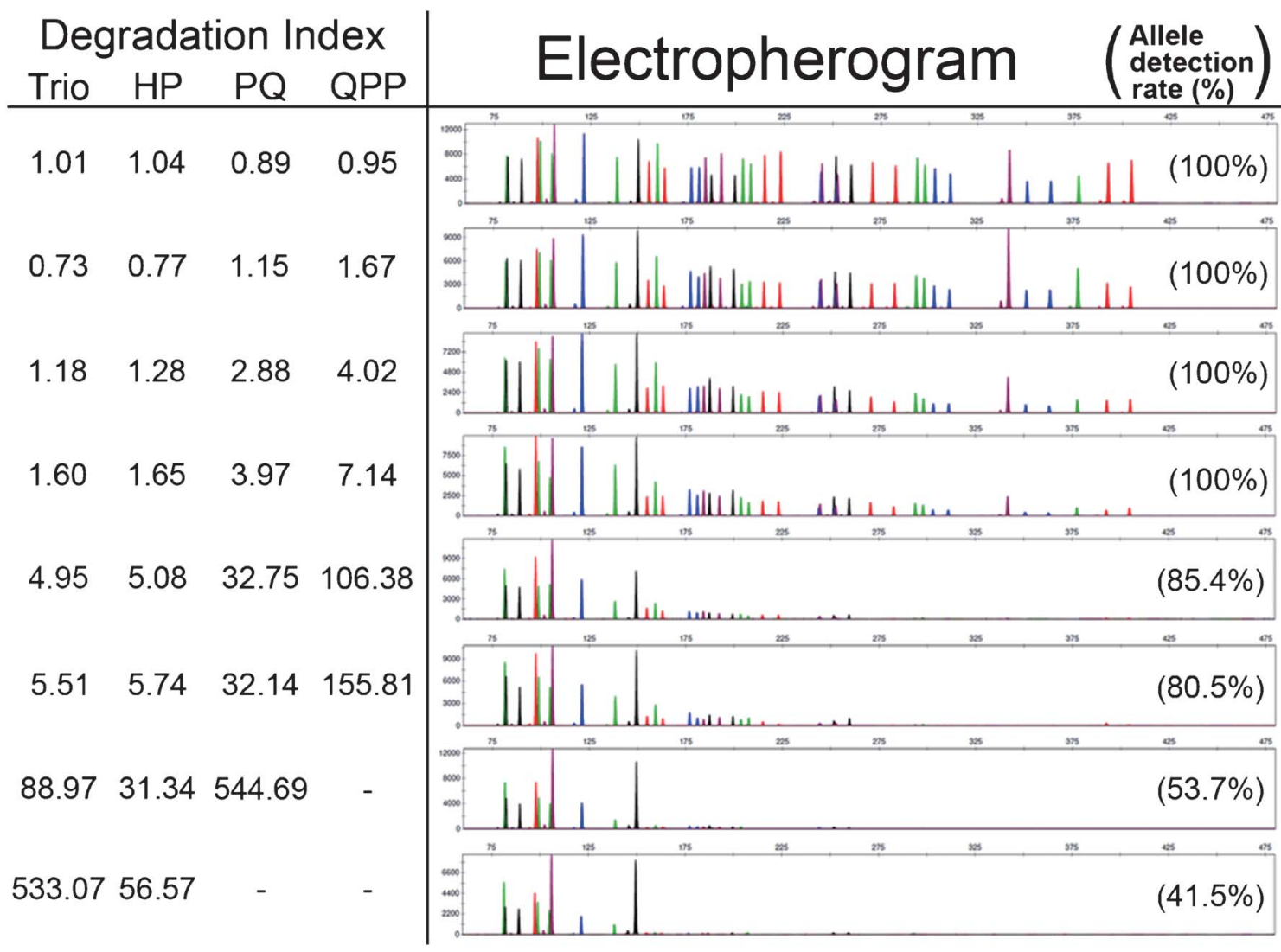

Fig. 3 The relationship of Degradation Index and electropherograms. " - " means that degradation index was not calculated. Electropherograms are listed in the descending order of allele detection rate. For the samples with allele detection rate $100 \%$, the summation of Degradation Index of the 4 kits is arranged in ascending order.

Long の定量值が検出限界以下になったため，DI 值 が算出されなかった（Fig. 3, Table 3).

Table 3 より，同じDNA 溶液であれば Short の 定量值はキットにかかわらず近い值となったが， Long の定量值はキットによって大きく異なる場合 があった. Shortの定量值が近い值となった理由と しては, Shortの標的配列の塩基長が Trio および HP は 80 bp, PQ は 84 bp, QPP は 91 bp と類似し ていることが挙げられる（Table 1)。一方で, Longの定量值におけるキット間の差は，Long の 標的配列の塩基長が Trio および HP では $214 \mathrm{bp}$, PQ では 294 bp，QPP では 353 bp と大きく異なる ことから生じたと考えられる（Table 1)．このこと から，異なるキット間での DI 值の比較は困難と考 えられる.

これらの比較検討から，同じ TaqMan 法に基づ
いたヒト DNA 定量キットでも，キットごとに異な る特徵があることがわかった。ヒト DNA 定量キッ 卜を鑑定実務で使用する際には，これらの特徴を理 解しておくことが必要である.

\section{文 献}

1) Butler J. M., Genetics and genomics of core short tandem repeat loci used in human identity testing. J. Forensic Sci., 51, 253-265, 2006.

2 ) Thermo Fisher Scientific, User Guide: Quantifiler ${ }^{\mathrm{TM}}$ HP and Trio DNA Quantification Kits. available from [https://assets.thermofisher. com / TFS-Assets / LSG / manuals / 4485354.pdf ], accessed Jun 21, 2021.

3) Promega, Technical Manual: PowerQuant ${ }^{\circledR}$ System. available from [https://www.promega. 
jp / - / media / files / resources / protocols / technicalmanuals101/powerquant-system-technical-manual. pdf?la $=e n]$, accessed Jun 21, 2021.

4) Qiagen, Handbook: Investigator ${ }^{\circledR}$ Quantiplex $^{\circledR}$ Pro Handbook. available from [https://www. qiagen.com / jp / resources / download.aspx?id = 901fab34-fae8-4247-bc24-057840b27c50\&lang = en], accessed Jun 21, 2021.

5）タカラバイオ株式会社, ヒトゲノム DNA 定 量キットVer.2（RR281）説明書， 2011.

6) 中原弘明, 藤井宏治, 水野なつ子, 吉田日南 子, 笠井賢太郎, 法生物学的試料由来の DNA に対する定量法の検証. 日本法科学技術学会 誌， 12, 13-26, 2007.

7) Allison H., Sharon C. W., Julio J. M., Pius M. B., Emanuel L. and Robert L. G., Developmental validation of the Quantifiler ${ }^{\circledR}$ HP and Trio Kits for human DNA quantification in forensic samples. Forensic Sci. Int. Genet., 21, 145-157, 2016.

8) Ewing M. M., Thompson J. M., McLaren R. S., Purpero V. M., Thomas K. J., Dobrowski P. A., DeGroot G. A., Romsos E. L. and Storts D. R., Human DNA quantification and sample quality assessment: Developmental validation of the PowerQuant ${ }^{\circledR}$ system. Forensic Sci. Int. Genet., 23, 166-177, 2016.

9) Qiagen, Validation Report: Developmental validation of the Investigator ${ }^{\circledR}$ Quantiplex ${ }^{\circledR}$ Pro Kit. available from [https://www.qiagen.com/jp / resources / download.aspx?id = e80c5169-8cd14906-9359-de26fa0afdcf\&lang $=$ en], accessed Jun 21, 2021.

10) Feuk L., Carson A. R. and Scherer S. W., Structural variation in the human genome. Nat. Rev. Genet., 7, 85-97, 2006.

11) Krenke B. E., Nassif N., Sprecher C. J., Knox C., Schwandt M. and Storts D. R., Developmental validation of a real-time PCR assay for the simultaneous quantification of total human and male DNA. Forensic Sci. Int. Genet., 3, 14-21, 2008.
12) Qiagen, Supplementary Protocol: Investigator ${ }^{\circledR}$ Quantiplex $^{\circledR}$ Pro Protocol for the Applied Biosystems $^{\circledR}$ QuantStudio $^{\text {TM }} 5$ Real-Time PCR System.

13 ) Thermo Fisher Scientific, User Guide: GlobalFiler $^{\mathrm{TM}}$ and GlobalFiler ${ }^{\mathrm{TM}}$ IQC PCR Amplification Kits. available from [https://assets. thermofisher.com / TFS-Assets / LSG / manuals / 4477604.pdf], accessed Jun 21, 2021.

14) Thermo Fisher Scientific, User Guide: Yfiler ${ }^{\mathrm{TM}}$ Plus PCR Amplification Kit. available from [ https: / / assets.thermofisher.com / TFS-Assets / LSG/manuals/4485610_YfilerPlus_UG.pdf], accessed Jun 21, 2021.

15）藤井宏治, 綿引晴彦, 三田裕介, 北山哲史, 中原弘明, 水野なつ子, 関口和正, GlobalFiler による STR 型検査の法科学的評価. 日本法科学 技術学会誌，21，1-23, 2016.

16）綿引晴彦, 藤井宏治, 深川貴志, 三田裕介, 北山哲史, 中原弘明, 水野なつ子, 関口和正, Yfiler ${ }^{\mathrm{TM}}$ Plus PCR Amplification Kit を用いた YSTR 型検査の法科学的評価日本法科学技術学会 誌, 23, 13-34, 2018.

17) Fujii K., Fukagawa T., Watahiki H., Mita Y., Kitayama T. and Mizuno N., Ratios and distances of pull-up peaks observed in GlobalFiler kit data. Leg. Med., 34, 58-63, 2018.

18) Thermo Fisher Scientific, Technical Note: Artifacts Identified Post - Developmental Validation: GlobalFiler and GlobalFiler IQC PCR Amplification Kits. available from [https://assets. thermofisher.com / TFS-Assets / GSD / TechnicalNotes/globalfiler-kit-artifacts-tech-note.pdf], accessed Jun 21, 2021.

19) Watahiki H., Fujii K., Fukagawa T., Mita Y., Kitayama T. and Mizuno N., Differences in DYF387S1 copy number distribution among haplogroups caused by haplogroup-specific ancestral Y-chromosome mutations. Forensic Sci. Int. Genet., 48, 102315, 2020. 